\title{
The refugees of Rwanda seen through the eyes of a psychiatrist
}

\author{
O. J. Rooke
}

\section{Socio-political background}

Rwanda was the most densely populated country in Africa. It is two-thirds the size of Switzerland but contained a larger population (9 million people), growing by almost $40 \%$ every two years. Few square inches are left uncultivated. The Tutsi people (never more than $14 \%$ of the population) are said to have arrived in the 14 th century $A D$, bringing with them a feudal and totalitarian system of government. There was significant intermarriage with the result that today the Hutu and Tutsi people share the same language, cultural beliefs and religions (predominantly Catholic). In reality the terms Hutu and Tutsi now more accurately describe caste than ethnicity (Delcros, 1994).

When the Belgians gained control of Rwanda in 1919, they decided to educate only the ruling Tutsi minority, staffing the civil service, army and hospitals with them. They issued everybody with an identity card describing their 'ethnicity'. In 1959, soon before leaving they connived in a Hutu revolt which resulted in the Hutu gaining power. At least 20000 Tutsi were killed and 200000 fled the country, some of them forming an exile army based in Uganda, the Front patriotique rwandais (RPF). Since then the government, though recently attempting to introduce some sharing of power, has been Hutu dominated. The remaining Tutsi were barred by a quota system from many jobs in the public sector and therefore turned to commerce. Their resulting wealth enabled them to keep some of their former power. Rwanda, for a developing world country was remarkably well developed with a high level of literacy, tarmacked roads and electricity in many city houses.

The 1990s saw an economic down-turn and a resurgence of extremist nationalistic groups and militias. A Hutu group set up a private radio station, Radio Mille Collines. In August 1993 it began broadcasting, inciting fear and hatred of the Tutsi minority, repeatedly dehumanising them by describing them as cockroaches. On 6th April 1994, the aeroplane carrying president Habyarimana, president of Rwanda, together with the president of Burundi was destroyed by a missile. The Hutu militias immediately started the slaughter. Radio listeners were encouraged to spare 'not a single enemy' - the enemy being all Tutsi, friends of Tutsi and all 'moderates' (any supporter of an opposition party). More than half a million people died, the vast majority being Tutsi. The RPF immediately invaded from Uganda driving the Rwandan government army along with more than two million Hutu civilians into Tanzania and Zaire. The scale of the exodus overwhelmed the ability of the United Nations High Commission for Refugees and the non-governmental organisations (NGOs), which it coordinates, to prevent further massive loss of life.

\section{The refugees: a personal account}

In July 1994 I agreed to be the expatriate doctor for about twenty thousand Rwandan refugees (all of them Hutu) in Tanzania. In a briefing before my departure, I was told that a significant proportion of the adults in the refugee camp had taken part in the genocide. I felt rather intimidated, I remembered once seeing a patient with schizophrenia who would occasionally hear voices on the radio commanding him to kill people. It distressed him greatly but he had never resorted to violence. It was difficult to understand why these radio listeners had been so obedient. Following encouragement to 'crush all the cockroaches', one in twenty of the population were murdered. I expected to encounter a very abnormal people.

The refugees had also suffered. Most of the families arriving in the camp had lost at least one member. Both extremists and moderates feared to go back, particularly as a small trickle of people with fresh wounds continued to walk into the camp for some months. Some 
of the escapes astounded me. Three children walked into the camp, the back of their skulls having been sliced off with sharpened hoes. All three lived. I was surprised to learn that the hoes were generally wielded by women, the men using the family machete.

The refugees did not look particularly violent. Initially they got on with the business of survival in a calm, if rather apathetic, way. The absence of emotion in the camp did not strike me until a month after my arrival, when for the first time there I saw someone cry. She was a young woman tending her husband who was dying of cerebral malaria in the large building made of wooden poles and blue plastic sheeting which we called a hospital. I thought that I was witnessing a massive prevalence of posttraumatic stress disorder, but the other characteristic symptoms were not to be elicited. The refugees themselves put their lack of emotion down to sheer exhaustion. Not long after the first woman cried, it became common to see normal grief. With the tears came laughter, anger and all the other emotions which had previously been absent. But with them also came further murder. Bodies covered in knife wounds would be left for the charitable agencies to collect in the mornings. The extremists had not finished their work.

In the clinic the only convincing psychiatric cases I saw were two cases of mania and one of a severe depressive illness. It wasn't that the refugees were afraid of bringing trivial complaints to our attention. The commonest presenting symptoms were those of upper respiratory tract infections. It could of course be that only those with enough energy and initiative attended. There were also hidden agendas, some of our prescriptions ended up on the local market.

I had been expecting the children to be obviously brutalised, but once they gathered enough twigs and bits of wire to make toys, they made cars not guns. The adult refugees also emerged as kind and fun loving people. There was no need to build an orphanage for the hundreds of orphans registered by the Red Cross. Every one of them had been taken in by a family. I heard stories of outstanding courage, of people who had risked their lives by sheltering Tutsi, of others who had been killed for refusing to join in the massacres, a commonly used test of patriotism.

In emergency situations, the refugees themselves are usually employed to staff the medical services, but among the twenty thousand people we found only two nurses and two medical assistants. We had to train a further fifty people in medical skills. We took lawyers, accountants, teachers, indeed anyone who could speak French and seemed keen to become a health worker. The reason for the disproportionate scarcity of doctors and nurses was explained by one of our medical assistants. He claimed that in this long running feud between the Tutsi and the Hutu, the educated elite were generally the first to be killed. This is because it is impossible to form an opposition party or even an effective army without anyone who can read or write. He told me that in 1972, in Burundi (a neighbouring country with an identical ethnic breakdown), the Tutsi, being in power, killed every Hutu who had been to secondary school (this accusation turns out to be substantially true). Our medical assistant understood the danger that his education put him in. He fled disguised as a peasant.

Our recruits learned quickly. I was amazed by the quality of the education that some had received, they spoke four languages, and took pride in quoting French philosophers of whom I had never heard. They were kind, conscientious, cheerful and efficient. Together we reduced the mortality rates significantly, from burying eight children a day to one. I was very proud of them. It was only later that I learned that some of them had taken part in the genocide.

One day a worker told us that another of our employees was in grave danger. She was a Tutsi who had married a Hutu. During their flight from Rwanda her husband had been kdlled, so that she was alone in the camp with her Hutu children. (Officially children take on the ethnicity of their fathers, there are no half castes.) Some refugees had decided that she was dangerous and had to be killed. To save her life we would have to evacuate her immediately. We questioned four of our recruits about her. We knew them well, they were some of the first people whom we had trained. We asked whether her life was really in danger, or whether they thought that our informant was being melodramatic. We couldn't understand how she could possibly pose a threat to other refugees.

'She could be a danger and she must be killed.' was the reply. 'You will find lots of Patriotic people willing to do it, all four of us here are patriots and have killed.' They added that she might be a spy and that she may have poisoned some of our patients already (a ludicrous suggestion).

Later we heard rumours that others among our recruits had taken part in the genocide. 
That we had chosen some 'assassins' (as the refugees called them) to work for us disturbed us deeply. I think we had believed that people capable of such viciousness would be instantaneously recognisable, or perhaps that educated people would be immune to the propaganda and would not have participated. But it bothered us more than it bothered the refugees. I asked a refugee what we should do. I knew her to be a moderate who had lost many friends, killed by the extremists. You can't do anything she said, 'It would be dangerous, anyway they're good at their job and everybody trusts them.' Strangely enough everybody did trust them. People injured by the Tutsi RPF army had their wounds dressed side by side with those injured by the Hutu vigilantes, colleagues of some of those now doing the dressing.

Perplexed that the victims and their attempted murderers could live in such close proximity with no outward sign of animosity, I asked my friend whether she thought that the Rwandan people could ever forgive and forget. 'Never' she said, 'After all we're only normal human beings.' It was precisely their normality which I found so very disturbing.

\section{Conclusions}

If my brief had been different and I had been asked to provide 'psychiatric aid', I would have found it difficult to know what to do.

In the initial chaos everybody seemed traumatised. Later, people with clear signs of posttraumatic stress disorder or other neuroses seemed scarce and certainly didn't present themselves for help. Even if sufferers could be identified, there are many difficulties. The concept of counselling by strangers was not known to the refugees that I spoke to. According to them, the only honourable forum in which to express distress was within the extended family. Some of the 'victims' will also have been perpetrators. Helping them may be seen as unpalatable by the charities providing funds. Focusing on women and children as victims doesn't solve the problem as they also took part in the killing. The youngest defendant in Kigali prison charged with genocide is apparently aged just seven (Cook, 1995).

What does one do with staff who condone the genocide or those who are rumoured to have taken part? There is no doubt that many of the refugees saw themselves as a people at war and sought to justify the killings as an act of war. Very few of the refugees were brave enough to publicly condemn the killing, and in employing only those who did, one would alienate the service from the vast majority of the refugees.

As it seems that further conflict is likely, I believe that it is debatable whether searching out and treating diagnostic concepts like posttraumatic stress disorder is really a priority at the moment. In my view, tackling some of the abnormal sociological phenomena may be a more useful aim. For instance, the ease with which the mass media was able to dehumanise people and hence legitimise their extermination is particularly disturbing. Attempting to re-humanise the 'enemy' might well benefit the refugees by minimising the violence of any future conflicts. Unfortunately attempts to do so would be very unpopular with the refugees' leaders, and possibly be very dangerous.

I have speculated as to how the genocide was made possible - by dehumanising the Tutsi. The reasons why it happened in that particular country are more unclear. One contributing factor may be the speed at which the already dense population was becoming denser. Rwanda was one of ten countries cited by King in 1993 as being 'demographically entrapped', one of the four possible outcomes of demographic entrapment being that the population "be destroyed by war or genocide' (King, 1990). When in former times Europe was confronted with a similar explosion, its excess population emigrated, often committing genocide on the native peoples. The Rwandan people don't have anywhere to emigrate to. There is also the awful possibility that from the ethological point of view, mass killing in an overcrowded situation is both inevitable and 'normal'. When researchers gave various species of primates ample food but limited space, the populations were controlled by extreme violence, including orgies of mass killing (Russell \& Russell, 1968). These issues, though difficult and uncomfortable have to be tackled if a repeat catastrophe is to be avoided.

\section{References}

Сook, R. (1995) The danger of another Rwanda. Independent On Sunday. 9th April.

DelCros. L. (1994) La Question Ethnique au Rwanda. Brussels: Brureau International de Médecins sans Frontières.

Kivg, M. (1990) Health is a sustainable state. Lancet, 336 , 664-667.

- (1993) Demographic entrapment. Transactions of the Royal Society of Tropical Medicine and Hygiene, 87 (suppl. 1). 23-28.

Russell, C. \& Russel. W. M. S. (1968) Violence, Monkeys and Man. London: Macmillan.

O. J. Rooke, 75 Mornington Road, Greenford, Middlx UB6 9HN 